\title{
Inequalities in the education system and the reproduction of socioeconomic disparities in voting in England, Denmark and Germany: the influence of country context, tracking and self-efficacy on voting intentions of students age 16-18
}

\author{
Bryony Hoskins $^{\mathrm{a} *}$, Jan Germen Janmaat ${ }^{\mathrm{b}}$, Christine Han ${ }^{\mathrm{b}}$ and Daniel Muijs ${ }^{\mathrm{a}}$ \\ ${ }^{a}$ Southampton Education School, University of Southampton, Southampton, UK; \\ ${ }^{b}$ Department of Lifelong and Comparative Education, Institute of Education, \\ London, UK
}

This article performs exploratory research using a mixed-methods approach (structural equation modelling and a thematic analysis of interview data) to analyse the ways in which socioeconomic disparities in voting patterns are reproduced through inequalities in education in different national contexts, and the role of self-efficacy in this process. The evidence suggests that in Germany and England students with lower socioeconomic status (SES) have lower levels of general self-efficacy, and that this is reinforced through early experiences of inequalities in the education system, such as within- or between-school selection. Low levels of general self-efficacy are then found to reduce political self-efficacy and voting intentions. In Germany and England, it is these students who enter initial vocational education and training (IVET). The experience of IVET then reinforces the distinctions in civic engagement, probably either through peer socialisation and/or curriculum differences. In Denmark, where SES has a weaker association with track placement, the experience of being placed in IVET plays a stronger role in reducing political self-efficacy and voting intentions.

Keywords: IVET; tracking; social class; self-efficacy; political participation; voting; equality; inequality; education system

'But there's nothing we can say about it because to them we're no one, we're a nobody.'

\section{Introduction}

In the interests of democracy and democratic equality, experiences of education ideally should not increase inequalities in democratic engagement (Bartels 2008; Levinson 2010). In this regard, it has been argued that inequalities in democratic engagement are enhanced by the practice, in

\footnotetext{
*Corresponding author. Email: B.Hoskins@soton.ac.uk 
many countries, of allocating young people to different tracks on the basis of what is described as their ability (Hyland 2006; Rubin 2007; van de Werfhorst 2009). These authors suggest that track placement on the basis of ability amounts to social sorting, with young people from working-class backgrounds disproportionately ending up in initial vocational education and training (IVET) schools/subjects. This class-based division is then thought to strengthen inequalities in future civic and political engagement (CPE) through either differences in the curriculum and/or peer socialisation effects. However, it has yet to be explored whether this relationship applies in countries differing in the prestige accorded to IVET, and whether inequalities in the education system prior to the allocation into different tracks also play a role. It could also be the case that socioeconomic status (SES) influences both track placement and CPE to the point of making the effect of track placement on CPE entirely spurious (Persson and Oscarsson 2010; Persson 2012). Drawing on quantitative survey data and qualitative interview data of 16-18-year-olds in IVET and post-compulsory general education in three countries, this article will perform some exploratory research to identify the extent to which inequalities in education generally, and the division of students into academic and general tracks in particular, contribute to the reproduction of inequalities in the intention to vote. It will examine how this effect changes according to country context and the role of self-efficacy, both in enhancing voting intentions and in commitment towards academic study.

There has been research that explores the effect of tracking on CPE in continental Europe, where single-country studies have been carried out in Israel (Ichilov 2002), Belgium (Stevens 2002), the Netherlands (Ten Dam and Volman 2003), Sweden (Persson and Oscarsson 2010; Persson 2012) and Germany (Eckstein, Noack, and Gniewosz 2012). Our study comprises three countries: Denmark, England and Germany. To the best of our knowledge, this is the first time the question of the experience of IVET on voting intentions has been addressed using a comparative approach. Exploring this question in the national contexts of Denmark, England and Germany is interesting as the education systems of the three countries vary considerably in key characteristics with respect to both lower- and upper-secondary education, as will be explained below. This research is also significant in terms of helping to provide an understanding of the role of the education system in inadvertently enhancing inequalities in democratic participation. The results therefore have the potential to provide an initial evidence base for highlighting possible changes in policy and practice for vocational education in England, and more broadly across Europe, with the aim of enhancing democratic participation. 


\section{Tracking, IVET and CPE}

There is an extensive body of literature on the effects of the numbers of years of education on CPE (Verba, Schlozman, and Brady 1995; Niemi and Junn 1998). However, the literature on the social and political effects of different educational tracks is much smaller. From this smaller field, there are different, and sometimes contradictory, findings. In fact, the only point in common among these findings is that students in IVET generally come from more disadvantaged backgrounds than students in the general track. The studies do find differences in CPE levels across tracks, and that there is an effect of track enrolment on CPE levels. Most studies claim that students in IVET have lower CPE levels than those in general education (e.g. Ichilov 2002; Stevens 2002; Lauglo and Øia 2006; van de Werfhorst 2007; Persson and Oscarsson 2010; Persson 2012). However, a study commissioned by the European Centre for the Development of Vocational Training (CEDEFOP) shows civic participation levels in some countries to be higher amongst IVET students than those in general education (Mostafa et al. 2011). There is also a point of contention in the literature regarding how and when the civic attitudes of students in IVET and general education are formed. One group of scholars holds that enrolment in IVET has a distinct impact on CPE through the curriculum and socialisation experience with peers (Ichilov 2002; Stevens 2002; van de Werfhorst 2007; Mostafa et al. 2011). The alternative position is that enrolment in vocational or general tracks merely reflects sociocultural status, and that it is the latter that fundamentally shapes CPE (Persson 2012).

We will now examine these positions and their contrasting findings in greater detail. The literature on the negative effect of IVET postulates three mechanisms through which IVET is linked with lower CPE: (1) curriculum, (2) peer experience and (3) sense of failure. With regard to the curriculum, Ten Dam and Volman (2003), van de Werfhorst (2007) and Janmaat and Mons (2011) hold that students in the vocational track are, as a rule, offered a watered-down version of citizenship education, or a version that is aimed at fostering social skills and appropriate behaviour, rather than political knowledge and critical thinking skills. They argue that CPE levels among IVET students are further undermined by the experience of interacting predominantly with peers of lower social class and immigrant backgrounds, since these social groups are disproportionately represented in IVET (Hallinan 1994; Crul and Vermeulen 2003). What this means is that IVET students are isolated from groups that could help them towards being more active in CPE. As a result, they develop different life worlds and group cultures, with different norms and values. Also, the longer the experience of being educated in separate tracks, the more different the norms and values of IVET and general track students are likely to be (van de Werfhorst 2007; Janmaat and Mons 2011). 
Stevens (2002) adds a psychological dimension to the argument. He contends that, as enrolment in IVET is more often due to selection based on poor performance than the result of a conscious choice, it leads to a sense of failure among IVET students and to the belief that the outside world is a dangerous and hostile place unresponsive to their needs. In his study of 16-18-year-old students from 89 schools in Flanders, Stevens found a noticeable social and cultural divide between students in different tracks. Students in the vocational track participated less in social organisations (voluntary organisations, political parties and human rights, environmental, anti-racist, peace, third world, cultural or neighbourhood associations) and expressed more intolerant and undemocratic attitudes than those enrolled in general tracks. Stevens likened the cultural distinction between the two school types to the difference between the two Belgium comic characters, Spirou and Tintin, by suggesting that the vocational students had the more 'tough and rebellious' image portrayed by Spirou, while those in the general track closely resembled the more mainstream 'innocent and respectable' character of Tintin.

Using the International Adult Literacy Study data from 17 countries to examine CPE among adults, van de Werfhorst (2007) also found that those with vocational qualifications had markedly lower levels of volunteering and political interest. He also found that the earlier young people were selected into distinct general and vocational or pre-vocational tracks, the larger the gap in volunteering between the two groups.

In contrast to the negative effect thesis as stated above, Mostafa et al. (2011) argue that IVET can actually have positive effects on CPE, depending on the social context (CEDEFOP 2011). In environments where IVET qualifications have social prestige and are valued by employers, vocational tracks are conducive to the development of strong professional identities, which in turn enhance trust, involvement in professional networks and civic participation more generally. This thesis builds on the work of Goffman (1959), who claims that an individual's occupation or profession is crucial for the understanding of the self. However, in contexts where IVET has less social prestige, these mechanisms are unlikely to apply and IVET may well be related to lower CPE levels.

Drawing on the literature on the varieties of capitalism and human capital formation (Iversen and Stephens 2008), CEDEFOP researchers (2011) developed a typology of national IVET systems consisting of five types or models. ${ }^{1}$ Two of the models are relevant for the current article as these involve the countries in our study. The first is the apprenticeship-based model, which the CEDEFOP researchers associate with Germany and Denmark. The curriculum for this model is derived through consensus between social partners and employers. The model represents a highly regulated system: there is a school component and a component of training at the workplace and school time is spent predominantly on general education. In this 
model, IVET offers young people job prospects and the social prestige of IVET is high. The second model is a market-led one and characterises IVET provision in England. This model focuses predominantly on the development of skills for specific professions and offers little by way of general education. As the name of the model suggests, it is the employers who are said to have the greater influence over decisions with respect to the curriculum. As employers generally have little interest in including citizenship education in the curriculum, one could postulate that this approach reinforces the negative effect of IVET on social and political outcomes. The differences between the two models in the CEDEFOP (2011) typology lie in the status accorded to IVET qualifications, the quantity and quality of general education provided and the role played by social partners in the development of the curriculum.

A study has also been carried out by CEDEFOP researchers (Mostafa et al. 2011) using longitudinal data from the European Community Household Panel Survey. The data enabled them to control for previous levels of $\mathrm{CPE}$ and thus to assess the net effect of track enrolment. In their analysis of the pooled data, they found that IVET was positively related to club membership. This positive relationship was also found in the analysis of their German and Danish samples, that is, in the countries associated with the first model. In England, which belongs to the second model, they found no positive effect for either general or IVET education on club membership. Their conclusion was that education systems in countries with a more highly regarded vocational system, such as Denmark and Germany, were in a better position to promote civic identities than systems with weaker VET traditions.

Both the negative and positive effects theses described above share the assumption that track enrolment has an independent effect on CPE. However, some scholars argue that track enrolment is merely a proxy for early socialisation experiences. They are of the view that both school selection and voting intentions are predetermined by early childhood socialisation experiences, and the SES of the parents (Persson 2012). In this view, the link between IVET and lower CPE levels is nothing more than a spurious correlation. In other words, the formal education system is taking credit (or blame) for social outcomes that are not the result of the education system. Analysing Swedish panel data comprising a sample of 500 students in upper-secondary vocational and general tracks, Persson (2012) does not find a distinct effect of track enrolment once previous levels of CPE are controlled for. He thus concludes that the lower levels of CPE in the vocational tracks are simply due to selection effect. These findings are similar to those of Kam and Palmer (2011), who develop a similar argument in regard to their findings of the non-effects of higher education on social outcomes. One of a number of possible explanations they give is that students can learn from their parents the feeling of being 'efficacious, competent, and 
self-assured' and that this can drive both education achievement and political engagement (65).

From the three contrasting perspectives discussed above, we developed the following rival hypotheses:

(1) The negative effects hypothesis (H1): enrolment in IVET undermines CPE.

(2) The context effect hypothesis (H2): the effect of enrolment in IVET on CPE depends on the context; in contexts where IVET is highly institutionalised and IVET qualifications have social prestige, IVET has positive effects on CPE; in contexts where IVET has low social prestige, it has a negative effect on CPE.

(3) The 'no direct effect' hypothesis (H3): CPE levels are lower among IVET students, but this is not the result of track placement; it is due to young people with low CPE levels disproportionately enrolling in IVET tracks.

\section{Intention to vote and political self-efficacy}

Voting intention is the outcome on which this study focuses. Behavioural intentions of young people have been widely used to offer an insight into future political behaviour (Hooghe 2004; Hooghe and Wilkenfeld 2008) and theories of political psychology would suggest that young people's early development of political attitudes and behaviours has persistent lifelong effects (Sears and Levy 2003). In addition, empirical evidence shows that there is an association between voting intention and actual voting (Achen and Blais 2010) and recent longitudinal research has found youth intention to vote to be a strong determinant of actual levels of adult voting (Kahne, Lee, and Feezell 2013). Furthermore, voting is an activity that has fewer demands in terms of resources with respect to time, money or education than, for example, contacting a politician (Verba, Schlozman, and Brady 1995) and, at least in theory, should be more open to wider participation.

Political participation, such as voting, depends in part on an individual's level of self-efficacy. However, personal efficacy can be negatively affected by low self-esteem, one of the attributes associated with attending IVET. Self-efficacy is defined as, 'beliefs in one's capabilities to organize and execute the courses of action required to manage prospective situations' (Bandura 1995, 2). Political self-efficacy refers to the exercise of such beliefs in the political domain. We selected political self-efficacy for our analysis because there is a great deal of evidence from the field that high political self-efficacy drives political engagement (Haste 2004; Power and Power 1992; Veugelers and Vedder 2003; Veugelers 2007). Therefore, if students do not feel they know much about politics relative to people their age, have little interest in politics, are not able to understand political issues 
easily and have no views on political issues, then their perceived political self-efficacy is low. Bandura's (1995) prediction is that, in situations of low self-efficacy, people will 'shy away from difficult tasks' and that 'because they view insufficient performance as deficient aptitude, it does not require much failure for them to lose faith in their capabilities' (11). We could posit that the experience of failure associated with having to take up IVET as opposed to a general education track could be a factor that reduces feelings of self-efficacy in general and that this could, in turn, have an effect on self-efficacy in the political domain. Political self-efficacy could thus be an important mediating variable between school track (IVET or general education) and voting intentions. Therefore we can formulate a fourth hypothesis as follows:

(4) The mediated negative effect hypothesis (H4): the effect of track enrolment on voting intentions is mediated by political self-efficacy.

\section{Data source}

From autumn 2009 to spring 2011, the Economic and Social Research Council's Learning and Life Chances in the Knowledge Economy and Society (ESRC LLAKES)-funded project on inequalities collected data among adolescents and young adults in European and Asian countries. The project aimed to assess how young people experience, perceive and evaluate inequalities in different national contexts, how these appraisals of inequalities are linked to objective inequalities - for example differences in wealth and civic attitudes - and how such appraisals affect attitudes to social cohesion, such as political participation. Both qualitative and quantitative data were collected. Respondents were young people in lower-secondary, upper-secondary and higher education. For this article we focus on the data collected from students in post-compulsory upper-secondary education in Denmark (Copenhagen), England (London) and Germany (Frankfurt). Respondents were predominantly 16-18 years old and were selected from two schools in each country, one providing general education (the students selected were all taking academic qualifications) and the other providing IVET (the students selected were all training for low- or semi-skilled professional jobs). We collected approximately 100 questionnaires in each school (see Table 1) and conducted about five student interviews at each institution.

As the sample consists of students from two non-randomly selected schools in each country, we cannot claim that the data are representative of all the students in upper-secondary education in the countries of the study. The results of our analysis, for instance regarding differences between countries in the effect of track placement on citizenship outcomes, can therefore only be understood as indicative. Our 'testing' of the aforementioned 
Table 1. Number of students in school types per country.

\begin{tabular}{llcc}
\hline Metropolitan area and country & School type & Frequency & Percent \\
\hline London, England & IVET & 103 & 47.7 \\
Copenhagen, Denmark & General & 113 & 52.3 \\
& IVET & 94 & 49.7 \\
Frankfurt, Germany & General & 95 & 50.3 \\
& IVET & 183 & 62.2 \\
& General & 111 & 37.8 \\
\hline
\end{tabular}

hypotheses is thus provisional at best. Nonetheless, since the selected schools were all from metropolitan environments, they are broadly comparable cross-nationally. Moreover, the findings of our analysis are worth reporting as they show dramatic cross-track differences for the outcomes of interest.

\section{Selection of countries}

In this article, we focus on Denmark, England and Germany because these countries vary in the key characteristic of prestige associated with IVET. The context effect hypothesis holds that the direction and the extent of the gap in voting intention depend on the social prestige of IVET in a particular country. As IVET has some measure of prestige in Germany and Denmark, this hypothesis would expect to find IVET students in these countries to have at least the same, if not higher, levels of CPE as students in the general track. In contrast, IVET in England has little social prestige and IVET students would therefore be expected under this hypothesis to lag significantly in their CPE levels relative to those in the general track.

In addition, these three countries are interesting as they differ in regards to the implementation of school selection prior to IVET. Germany selects at age 10 into different school tracks, while Denmark, in contrast, has a fully comprehensive system with strict mixed-ability classes until age 16 . In contrast, England formally has a comprehensive system, but one in which the practice of grouping by ability, particularly in the core subjects, is widespread within schools. The typical age for starting in the IVET system in all three countries is 16 . However, these prior experiences of inequalities may well influence our findings.

\section{Variables}

We developed latent variables consisting of a number of items from the questionnaire to tap voting intention and political self-efficacy. For the descriptive statistics we constructed these latent variables as scales. When conducting the structural equation modelling, we used individual manifest 
variables to construct latent variables within the model; this is explained in the methods section of the article. The scales represent internally coherent constructs in all three countries with alpha reliability values of .75 and higher (Table 2). These are summative indexes with values ranging between 0 and 10 , with the value 5 as the mid-point. Values below 5 reflect disagreement or less likelihood to varying degrees (i.e., negative responses). Values above 5 represent different degrees of agreement, or more likelihood (i.e., positive responses). These summative indexes have the advantage of not only allowing for easy cross-national comparisons, but also of assessing absolute scores, making these ideal for descriptive purposes. Absolute levels cannot be examined with scales reflecting factor scores or other standardised values.

The main outcome of interest for this article is the intention to vote. The scale on future voting comprised two items: (1) voting in national elections and (2) getting information about candidates. There were four possible responses to these items: 'I will certainly not do this', 'I will probably not do this', 'I will probably do this', 'I will certainly do this'.

In our models we also use the construct of political self-efficacy. The scale on political self-efficacy comprised four items. The items were: 'I know more about politics than most people [in my age group]', 'When political issues or problems are being discussed, I usually have something to say', 'I am able to understand most political issues easily', 'I am interested in politics'. The response categories were 'agree strongly', 'agree', 'neither agree nor disagree', 'disagree', 'disagree strongly'.

The error plots in Figure 1 show the differences in voting intention across track and country. Error plots are ideal for exploring mean differences between groups as they allow for a quick assessment of both the direction and the significance of these differences. If the confidence intervals, as represented by the bars, overlap, the group means are not significantly different. If they do not overlap, they are. Figure 1 shows that the students in IVET have a less positive attitude towards CPE on both indicators, in all three countries. Moreover, the difference between IVET students and general track students is significant in the three countries. With respect to the absolute values on future voting, all groups - except for the vocational group in England - are more positive than negative in their views on

Table 2. Reliability statistics for the scales for future voting and political self-efficacy.

\begin{tabular}{lcccc}
\hline Country & $\begin{array}{c}\text { Future voting } \\
\text { (Cronbach's alpha) }\end{array}$ & $\begin{array}{c}\text { Items } \\
(n)\end{array}$ & $\begin{array}{c}\text { Political efficacy } \\
\text { (Cronbach's alpha) }\end{array}$ & $\begin{array}{c}\text { Items } \\
(n)\end{array}$ \\
\hline England & .836 & 4 & .867 & 4 \\
Denmark & .791 & 4 & .865 & 4 \\
Germany & .836 & 4 & .886 & 4 \\
\hline
\end{tabular}




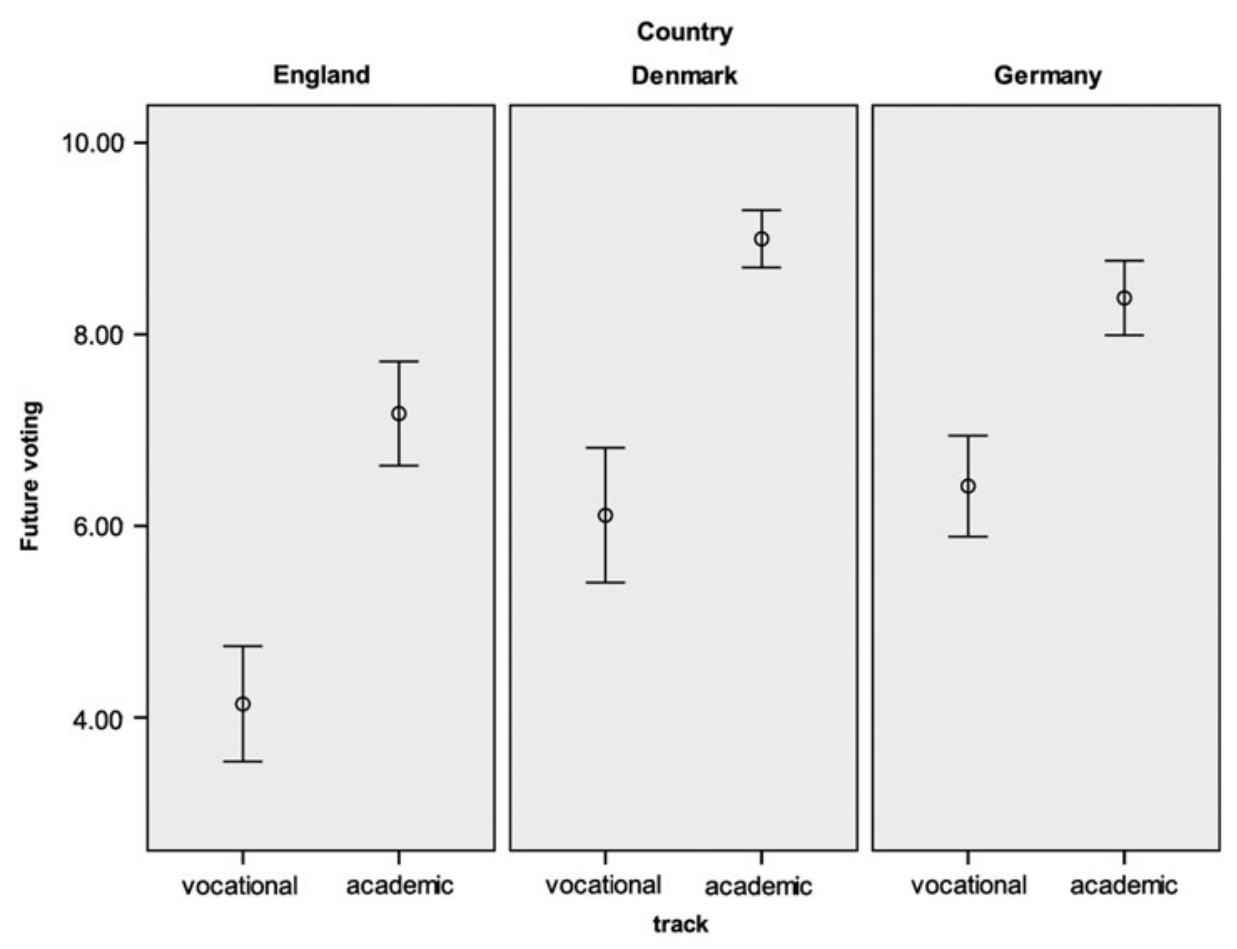

Figure 1. Error plots for voting intentions of students in either IVET or general academic education for England, Denmark and Germany.

whether they will vote when they become adults. It can further be seen that the difference in voting intention between the vocational and general groups is smallest in Germany.

With regard to political self-efficacy, students in the vocational track show negative responses (i.e., values below the mid-point) in all three countries, while students in the general group express positive views (see Figure 2). Again, the difference between tracks is smallest in Germany, up to the point of almost becoming statistically insignificant. Thus, across the three countries, the 'between track' gaps in political engagement are most pronounced in England and Denmark. However, as noted earlier, due to the non-random nature of the sample, these patterns should only be understood as tentative.

The key variable of interest in this article is track placement. This variable has the values 1 (IVET) and 2 (general education). As voting intention can be expected to be influenced by a number of individual background characteristics as well as track placement, we included the following control variables in the analyses: 


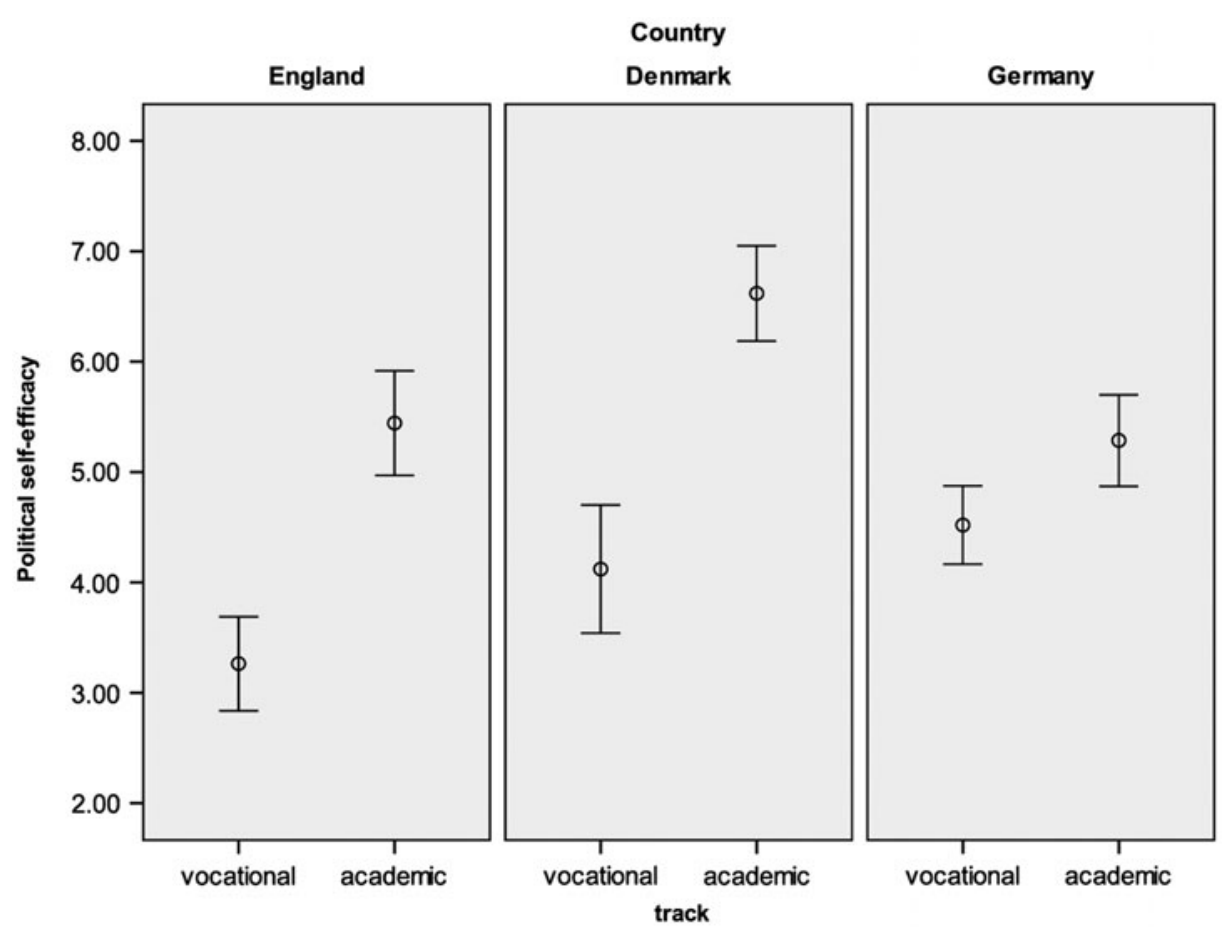

Figure 2. Error plots for political self-efficacy of students in either IVET or general academic education for England, Denmark and Germany.

- gender: female $=1$, male $=0$

- ethnicity: language of test spoken at home, with three responses: 'never', 'sometimes', 'always/almost always'

- cultural capital: number of books at home, with six responses: 'none', ' $1-10$ ', '11-50', '51-100', '101-200', 'more than 200'

- social background: mother's highest level of education, with four responses: 'left before completing lower-secondary', 'completed lowersecondary', 'competed upper-secondary', 'studied in higher education'. (In our data this variable has considerably fewer missing values than father's education level.)

The influence of these background characteristics on political engagement and other active citizenship outcomes has been well documented in the literature (on the effect of social background and cultural capital, see, for instance, Schulz et al. [2010]; on that of gender, see Hooghe and Stolle [2004] and Verba, Schlozman, and Brady [1995]; and for ethnic background, see Rice and Feldman [1997]). Unfortunately, we were not able to obtain measurements of CPE before the students in our study were enrolled in IVET or general upper-secondary education. We therefore cannot deter- 
mine the precise net effect of track enrolment. However, the inclusion of control variables in the models can partly compensate for the absence of previous measurements of the outcome variables.

\section{Methods}

In order to explore the relationship between school track and CPE, we conducted two types of analysis. First, we conducted structural equation modelling (SEM) using Mplus and, second, we conducted thematic analysis of the qualitative data.

Structural equation modelling has been defined as, 'a comprehensive approach to testing hypotheses about relations between variables' (Hoyle 1995, 10). This technique, which measures the fit of pre-specified directional relationships between the variables to the covariance matrix used, allows us to model directional relationships between variables whilst also taking into account measurement error in the data. One of the advantages of SEM is that it allows us to model the data as indicators of underlying variables. This is theoretically sensible as in many cases, measurement is indirect. Error variances were fixed according to estimates of measurement reliability (see Hayduk 1997), with coefficients ranging from .05 (gender) to 0.2 (questionnaire data, including the dependent variables). The loadings of the latent variables on their indicators are given in Tables 3-5.

\section{Results}

We present the results of our analysis in two sections: the first section describes the results of the SEM, while the second section provides the results from thematic analysis of the qualitative data.

Table 3. Measurement model for Denmark.

\begin{tabular}{|c|c|c|}
\hline Latent variable & Indicator & $\begin{array}{l}\text { Path coefficient } \\
\text { (standardised) }\end{array}$ \\
\hline \multirow[t]{4}{*}{$\begin{array}{l}\text { Political } \\
\text { self-efficacy }\end{array}$} & $\begin{array}{l}\text { I know more about politics than people } \\
\text { my age }\end{array}$ & .64 \\
\hline & $\begin{array}{l}\text { When political issues or problems are being } \\
\text { discussed, I usually have something to say }\end{array}$ & .80 \\
\hline & $\begin{array}{l}\text { I am able to understand most political issues } \\
\text { easily }\end{array}$ & .80 \\
\hline & I am interested in politics & .83 \\
\hline \multirow[t]{2}{*}{$\begin{array}{l}\text { Voting } \\
\text { intentions }\end{array}$} & $\begin{array}{l}\text { Adult expectations to vote in national } \\
\text { elections }\end{array}$ & .82 \\
\hline & $\begin{array}{l}\text { Adult expectations to get information about } \\
\text { candidates before voting in an election }\end{array}$ & .84 \\
\hline \multirow{2}{*}{$\begin{array}{l}\text { Socioeconomic } \\
\text { status }\end{array}$} & Number of books in home & .62 \\
\hline & Mother's level of education & .63 \\
\hline
\end{tabular}


Table 4. Measurement model for England.

\begin{tabular}{|c|c|c|}
\hline Latent variable & Indicator & $\begin{array}{l}\text { Path coefficient } \\
\text { (standardised) }\end{array}$ \\
\hline \multirow[t]{4}{*}{$\begin{array}{l}\text { Political } \\
\text { self-efficacy }\end{array}$} & $\begin{array}{l}\text { I know more about politics than people } \\
\text { my age }\end{array}$ & .77 \\
\hline & $\begin{array}{l}\text { When political issues or problems are being } \\
\text { discussed, I usually have something to say }\end{array}$ & .78 \\
\hline & $\begin{array}{l}\text { I am able to understand most political issues } \\
\text { easily }\end{array}$ & .77 \\
\hline & I am interested in politics & .87 \\
\hline \multirow[t]{2}{*}{$\begin{array}{l}\text { Voting } \\
\text { intentions }\end{array}$} & $\begin{array}{l}\text { Adult expectations to vote in national } \\
\text { elections }\end{array}$ & .82 \\
\hline & $\begin{array}{l}\text { Adult expectations to get information about } \\
\text { candidates before voting in an election }\end{array}$ & .93 \\
\hline \multirow{2}{*}{$\begin{array}{l}\text { Socioeconomic } \\
\text { status }\end{array}$} & Number of books in home & .77 \\
\hline & Mother's level of education & .56 \\
\hline
\end{tabular}

Table 5. Measurement model for Germany.

\begin{tabular}{|c|c|c|}
\hline Latent variable & Indicator & $\begin{array}{l}\text { Path coefficient } \\
\text { (standardised) }\end{array}$ \\
\hline \multirow[t]{4}{*}{$\begin{array}{l}\text { Political } \\
\text { self-efficacy }\end{array}$} & $\begin{array}{l}\text { I know more about politics than people } \\
\text { my age }\end{array}$ & .75 \\
\hline & $\begin{array}{l}\text { When political issues or problems are being } \\
\text { discussed, I usually have something to say }\end{array}$ & .82 \\
\hline & $\begin{array}{l}\text { I am able to understand most political issues } \\
\text { easily }\end{array}$ & .78 \\
\hline & I am interested in politics & .81 \\
\hline \multirow[t]{2}{*}{$\begin{array}{l}\text { Voting } \\
\text { intentions }\end{array}$} & $\begin{array}{l}\text { Adult expectations to vote in national } \\
\text { elections }\end{array}$ & .84 \\
\hline & $\begin{array}{l}\text { Adult expectations to get information about } \\
\text { candidates before voting in an election }\end{array}$ & .83 \\
\hline \multirow{2}{*}{$\begin{array}{l}\text { Socioeconomic } \\
\text { status }\end{array}$} & Number of books in home & .75 \\
\hline & Mother's level of education & .62 \\
\hline
\end{tabular}

\section{Results of the SEM and implications for the hypotheses}

We constructed a structural equation model to investigate the pathway relationships between students' SES, school track, political self-efficacy and voting intention. In terms of the reliability of the models created for the SEM, the Chi Square is significant at the .01 (though not at the .001) level, TLI and CFI both indicate good fit, with the indices being at or above .95 in most cases. The RMSEA, with values between .05 and .08 , also show good fit. The fit is slightly stronger in Germany, and slightly weaker in Denmark, with England in an intermediate position. However, the differences between countries on model fit are very small (see Table 6). 
Table 6. Model fit for each country for the structural equation modelling.

\begin{tabular}{lccc}
\hline & Denmark & England & Germany \\
\hline Chi Square (sig.) & $56.1(.002)$ & $56.8(0.002)$ & $57.2(0.003)$ \\
TLI & 0.96 & 0.96 & 0.97 \\
CFI & 0.94 & 0.95 & 0.95 \\
RMSEA & 0.07 & 0.06 & 0.06 \\
\hline
\end{tabular}

Figures 3-5 show the results of the SEMs. For ease of reading, these figures depict only the relationships between the latent variables. The full model includes the paths from latent to manifest variables, the coefficients for which are given in Tables 3-5. Track has a direct and significant relationship with voting in all three countries. Thus, in all countries, those in the general track were more likely to vote, providing evidence to support $\mathrm{H} 1$, 'the negative effect'. However, this relationship was strongest in England and weakest in Germany, providing support for $\mathrm{H} 2$, 'the context effect', as the effect is smaller in the country in which IVET is most prestigious. Where $\mathrm{H} 3$ is concerned, we found that the relationship between SES and school track is strong, and most pronounced in England (Figure 3), less strong in Germany (Figure 5) and weak and not significant in Denmark (Figure 4). This suggests that in England there is a strong likelihood that students whose mothers have less education and who come from homes with less cultural capital will find themselves in IVET. This is also likely to be the case in Germany, but in Denmark social background seems not to matter for track enrolment in this sample. Moreover, there is no direct effect of SES on intention to vote, and the effect of track enrolment on intention to vote does not disappear when SES is included in the model. These findings are not consistent with $\mathrm{H} 3$ as this hypothesis predicts that the link between track enrolment and voting intentions would be completely driven by SES.

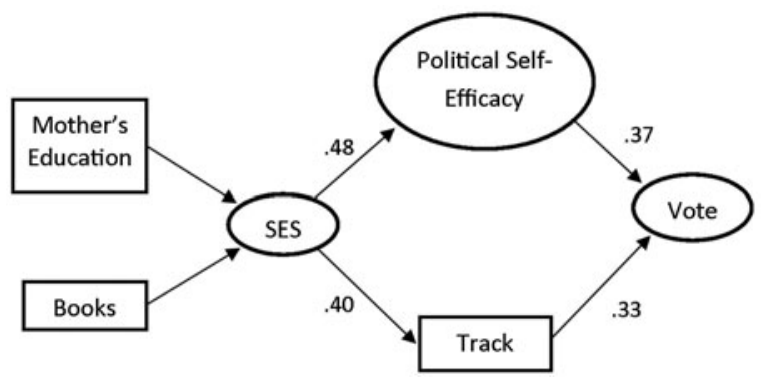

Figure 3. Structural equation model for future voting in England. 


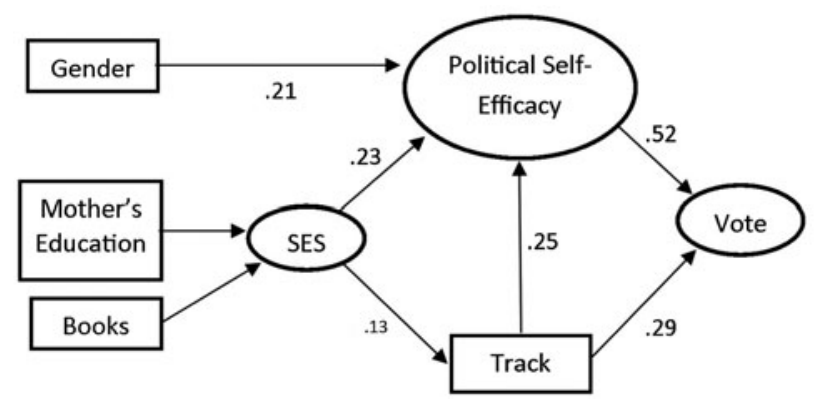

Figure 4. Structural equation model for future voting in Denmark.

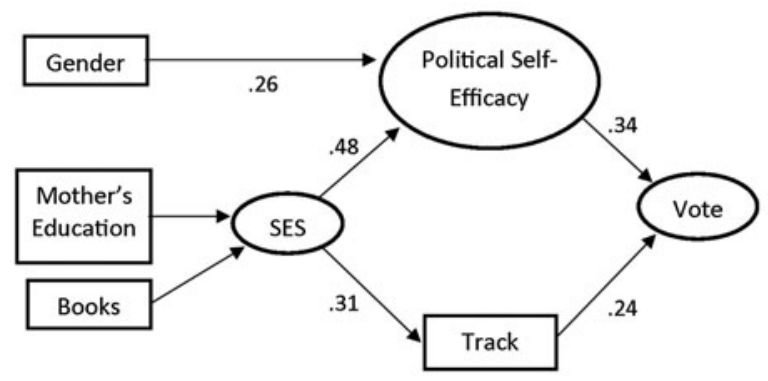

Figure 5. Structural equation model for future voting in Germany.

For all three countries, political self-efficacy has a mediating influence between SES and voting intention. Therefore, across the whole sample, those from families with less cultural capital and with mothers with less education have lower political self-efficacy and are subsequently less likely to vote. Only in Denmark does the model show support for the H4 'mediated effect', that is, that school track has a strong mediating influence on intended voting through political self-efficacy. Thus, in Denmark, the evidence suggests that being placed in the IVET track lowers the level of political self-efficacy, which, in turn, reduces the likelihood of voting. In contrast with the Danish results, in England and Germany there was only a strong, positive and direct relationship between track and future voting and no significant relationship between track and political self-efficacy. Therefore students in general education in England and Germany are more likely to vote than IVET students, thus suggesting a direct effect between track and voting; but there is no evidence to suggest that it is mediated by political self-efficacy.

In Denmark and Germany, political self-efficacy has a mediating influence between gender and voting intentions. This means that male students in these countries have higher levels of political self-efficacy and are subsequently more likely to vote. This is not the case in England. Once again, 
we note that the non-random sampling and relatively small sample size mean that these results are only indicative and that, in addition, we cannot determine causal direction or exogenous variables. Nonetheless, our findings from the qualitative data, which we discuss in the next section, are broadly in line with the interesting cross-country patterns produced by the SEM analyses.

\section{The effect of prior experiences of inequality on future voting as mediated through school track: findings from the interview data}

The SEM suggests that, in England and Germany, SES has a direct influence on school track, and that track mediates between SES and voting intentions. The survey that we undertook was cross sectional, therefore we have no prior information on students' voting intention or political self-efficacy before they went into the vocational track and cannot use this to establish the precise effect of the track on outcome (viz voting intention). Using the qualitative data, however, we can find out more about the relationship between SES and experiences of social and educational inequalities - and the interaction of these - on young people and their voting intention. We will look specifically at two themes in the interview data: (1) prior experiences of unfair treatment and (2) the experience of being in the vocational or lower track.

The English IVET students' interviews reveal that many of these students had lived difficult lives and had had serious issues at their previous, lower-secondary schools. Our small sample included students with parents who were divorced multiple times, who had died, who were alcoholic and who were said not to care. Amy's experience was fairly representative in this respect:

She's [my mother] not bothered, she's never been bothered, she's not hands on. She gives me money, she makes sure I've got a roof over my head that's it. She spoils me at Christmas and birthdays, but she's not there for the mum-daughter chats, she's not there to give me a hug. And I hate it, but it's just one of them things, that's just how some families are ...

The students' life experiences included rape, bullying in school, sexual harassment at college and running away from home. With regard to their previous experiences of education, students reported being humiliated and bullied by teachers and support staff, as well as exclusion from school.

Some of the English students felt they were treated unfairly by their teachers and discriminated against on the basis of their reputation rather than actual behaviour. Ann believed, for instance, that she was targeted by teachers for being in the wrong crowd: 
They [the teachers] just started being rude and, like, if I did the slightest thing wrong, I'd get like really badly shouted at, or I'd get a detention, or thrown out of class, things like that. ... [And] just some of the things they said, like they shouldn't say ... when I was in like Year 8, I got told 'Oh, you live in London, so you'll be pregnant when you're 13', and things like that.

There was frequent mention by students as to how unequal treatment by teachers even resulted in their being placed in lower sets as a result of their behaviour and choice of friends, rather than for reasons of ability. Barbara is an example:

... in Maths I was put from Set 3 to Set 2, and then I got put up to Set 1, I got dropped back down to Set 2, and now I've got dropped to Set 4 because I was naughty. So I've been up and down. And throughout Year 10, I didn't have a Maths class, my teacher refused to teach me so I didn't have a Maths class. I didn't have a Science class either; they refused to teach me.

While students from Germany did not report the kind of difficult life stories the English ones did, those who came from the lower-track schools did refer to experiences of inequalities in the way they were treated. Stefan spoke about how an early school he had attended differentiated between children who were predicted to go to the various tracks by assigning them different colour codes and giving those who were likely to go to the grammar school (Gymnasium) better facilities. For him, tracking was essentially singling out the 'less obedient or undisciplined people' and 'packing' them into classes at the secondary modern (Hauptschule) he attended. He judged that very little was done to help this group of students and that the secondary modern was just a way to produce 'generations of cheap labourers'. He described students from the secondary modern in strong derogatory terms - they were 'the rubbish tip':

Saying you are a student from the secondary modern school is demoralising, and it [the school] sets them [students] off on the wrong track. They [those who put you in a secondary modern] are basically saying you're stupid, and that's the way it is.

If students have unsupportive families or experience inequalities in the way they are treated early on in their schooling, it is not surprising that a number of them express a lack of self-belief. Most of the English IVET students we interviewed had no aspirations beyond further education. A few, like Amy, explained this by referring to the need to deliberately limit their aspirations:

If I don't want it, I'm not going to get disappointed if I lose it; if I don't love, it won't hurt me if it goes .... Because if I think, 'Yeah, I'm going to do this, I'm going to succeed', if I don't, then I'll be really disappointed. That's why 
I am the way I am. I feel like if I don't believe, then it won't hurt if it don't happen.

For Stefan, a German IVET student, an outcome of having been to a secondary modern was that he was at a loss as to how to carve out a future for himself:

What kind of job can I do? Should I become a car mechanic, or work myself up [that way]?

Our interview sample is small and there are dangers in making generalisations. Nonetheless, it is interesting to note that Gerhard, a German IVET student from the grammar school (Gymnasium) track, had a very different attitude to Stefan. Although there had been bullying in his school, with girls being called 'slags' and young people 'mobbed' (bullied) for dressing differently, he nonetheless felt more confident about his future, and spoke of choosing between 'apprenticeship or university'. He attributes the choices he had to having attended a grammar school:

That's why I am happy my parents wanted me to go to a grammar school. Every child should have that chance.

Many of the IVET students in England and Germany had experienced inequalities with respect to their family and social background and the way the school treated them individually and educationally. Many of these experiences preceded their current IVET education. As was seen above, students with such experiences also expressed low levels of confidence and aspiration. The interview data therefore suggests that it is the experiences of inequalities in the social background and the school system prior to the more recent IVET experience that may be associated with lower levels of confidence and aspiration or, in other words, low self-efficacy.

Scholz et al. (2002) describe self-efficacy in general terms, as 'a broad and stable sense of personal competence to deal effectively with a variety of stressful situations' (243). Han, Hoskins, and Sim (2013) note that, while scholars like Bandura $(1995,2006)$ regard self-efficacy as being domain specific, others like Scholz et al. (2002) believe it to be general. Scholz et al. believe that although self-efficacy, 'should be conceptualised in a situation-specific manner ... the degree of specificity of generality varies with the context'; self-efficacy would therefore need to be conceived in very specific terms when it comes to something like 'solving an algebra problem', but much more generally when applied to 'broad optimistic self-beliefs' (Scholz et al. 2002, 243). In the examples from our interviews, it is clear that the lessons that some students draw from their life experiences are sometimes applied generally, for example in terms of an uncertainty as to how to go forward in life or the need not to have high expectations or aspi- 
rations. Applied in this general manner, the likelihood is that the kind of low-self efficacy that is found in the personal or educational domain will also be found in the political domain. If so, the effects of the experiences of social and educational inequalities - and the ways in which these interact will lead to low levels of self-efficacy which, in turn, could lead to low levels of CPE, including voting. Support for the hypothesis that there is a relationship between a low general self-efficacy and political self-efficacy can be found from the low levels of political self-efficacy reported by the English IVET students in response to questions on the then upcoming 2010 General Election. The IVET students described the powerlessness they felt when it came to influencing the political debate:

There's nothing we can say about it because to them we're no one, we're a nobody. (Julie)

I think that no matter what my point of view is, it's not going to change anything. (Sam)

We're not looked at, us little people, we're not; I just wish something could be done about bad things, but nothing ever can because that's life. (Jane)

The low levels of political self-efficacy described by the English IVET students were in stark contrast to the active engagement of the English sixth form college students in the 2010 election:

Yeah, I would have voted for Labour, yeah ... and the rest of my friends in college, who are 18 and over, did. I was in Balham Street, around Plaistow, giving out Labour leaflets, and putting them into houses.

In summary, the interview data suggest that reduced general self-efficacy for students in the IVET track derives not only from the home lives of the IVET students, but also from earlier experiences of inequalities in school, through activities like setting and school selection, as well as teacher perception and expectations. This experience of education inequalities may well contribute to lower levels of both general self-efficacy and political self-efficacy.

\section{Conclusion}

The findings from this article are exploratory since our analysis is based on a small cross-sectional data-set that was not based on a random sample. Nevertheless, the results indicate some interesting findings worth further investigation. In this section, we discuss the implications of our research findings towards the literature in this field and implications for policy.

The contribution of this research has been towards developing an understanding of the role of the education system in reproducing socioeconomic inequalities in voting patterns in diverse national contexts. By drawing on 
both the qualitative and quantitative data, we have been able to demonstrate the complexity of how country context, experiences of inequalities in the education systems and lower levels of political self-efficacy all contribute to the disparities in expected voting behaviour.

The students' differential experience of education according to their SES is important for future voting behaviours, but not always in ways that are expected. In contrast to Ichilov (2002), Stevens (2002) and van de Werfhorst (2007), the results of our study in Germany and England show that reductions in general self-efficacy through a sense of failure are not so much associated with being placed in an IVET track but are more of an ongoing process within the education system prior to this point. Nevertheless, there is a direct effect of track in these countries, and this could well be due to peer socialisation effects (Stevens 2002) and/or curriculum differences (Ten Dam and Volman 2003; van de Werfhorst 2007, 2009; Janmaat and Mons 2011). This study cannot tease out the extent that these two factors affect voting intentions and how country context may influence this. This is a suitable question for future study.

Nevertheless, experience of inequalities at school does play a role and, in contrast to Persson (2012), we do not argue that everything is due to early socialisation and family socio-cultural resources. This is because we found no direct effect of SES on voting intention in any of the three countries. Moreover, the inclusion of SES in the model did not eliminate the direct effect of either track placement or political self-efficacy on voting intention. At this point, it should be noted that in his study, Persson performed the first sweep of his two-stage panel research when students were already enrolled in the upper-secondary vocational and general tracks. His study therefore did not capture the experiences of inequalities within the education system prior to this point. In contrast, our study takes into consideration the prior experiences of inequalities in the education system - prior to placement in the vocational and general tracks - in Germany and England through qualitative accounts of young people's experiences. And the experiences described by the IVET students - which included unfair treatment and selective processes at school - appear to be associated with lower levels of confidence and aspiration, in other words, low general self-efficacy. Thus experiences of inequalities in the education system as a whole appear to matter in terms of reducing general self-efficacy, political self-efficacy and, subsequently, future voting.

This study has highlighted the importance of the national context of the IVET system when explaining the effects of selection into general and IVET tracks and, in particular, the importance of the prestige of the IVET system, which was first noted in the CEDEFOP comparative typology (Mostafa et al. 2011). Our study showed that, where IVET has a higher status, the effect of IVET on voting intentions appears to be reduced; where streaming is the norm and IVET has low prestige, SES has the strongest 
effect on IVET and IVET, in turn, has the strongest direct effect on future voting. This study has also contributed to the development of the CEDEFOP typology by adding the timing of and types of school selection within the general education systems prior to the divide into IVET and general tracks. In addition, our study shows that the practice of prior selection experiences within and between schools adds significantly to the understanding of a national VET system and towards understanding the students who attend IVET in the different countries. The addition of prior selection experiences to the typology may well have relevance for economic as well as political outcomes of education.

Finally, our study shows that national context has a particular importance when reflecting on the policy implications. In England, where IVET has the least prestige of the three countries, SES had the strongest association with track placement, and track placement had the strongest association with voting intention. In addition to this, drawing from the qualitative data, we found that young people's educational experiences of inequalities prior to placement in the vocational and general tracks were important for their general self-efficacy. We posit therefore that by maintaining inequalities in the education system through activities like setting, the English school system may actually reduce opportunities for young people in lower-SES groups with respect to future engagement in the formal political process. This is an important finding for democracy in England and deserves further investigation. More generally, strategies for improving the levels of prestige accorded to vocational qualifications in England could be useful in tackling inequalities in democratic participation.

\section{Funding}

This project was funded by the ESRC LLAKES-funded project on Inequalities (grant number RES-594-28-0001).

\section{Note}

1. The typology of post-compulsory systems of education developed by Dumas, Mehaut, and Olympia (2013) shows practically the same models.

\section{References}

Achen, C., and A. Blais. 2010. "Intention to Vote, Reported Vote, and Validated Vote." APSA 2010 Annual Meeting Paper.

Bandura, Albert. 1995. "Exercise of Personal and Collective Efficacy in Changing Societies." In Self-Efficacy in Changing Societies, edited by Albert Bandura, 1-45. Cambridge: Cambridge University Press.

Bandura, Albert. 2006. "Guide for Constructing Self-Efficacy Scales." In Self-Efficacy Beliefs of Adolescents, edited by F. Pajares and T. Urdan, 307-335. Greenwich, CT: Information Age. 
Bartels, L. M. 2008. Unequal Democracy: The Political Economy of the New Gilded Age. New York: Russell Sage Foundation.

CEDEFOP (European Centre for the Development of Vocational Training). 2011. Vocational Education and Training is Good for You: The Social Benefits of VET for Individuals. Research Paper No. 17. Luxembourg: Publications Office of the European Union.

Crul, M., and H. Vermeulen. 2003. "The Second Generation in Europe." International Migration Review 37 (4): 965-986.

Dumas, A., P. Mehaut, and N. Olympia. 2013. "From Upper Secondary to Further Education: European Models of Post Compulsory Learning." In The Dynamics and Social Outcomes of Education Systems, edited by J. G. Janmaat, M. Duru-Bellat, A. Green, and P. Méhaut, 46-69. London: Palgrave Macmillan.

Eckstein, K., P. Noack, and B. Gniewosz. 2012. "Attitudes toward Political Engagement and Willingness to Participate in Politics: Trajectories throughout Adolescence." Journal of Adolescence 35 (3): 485-495.

Goffman, E. 1959. The Presentation of Self in Everyday Life. Gloucester, MA: Peter Smith.

Hallinan, M. T. 1994. "Tracking: From Theory to Practice." Sociology of Education 67 (2): 79-91.

Han, C., B. Hoskins, and J. B.-Y Sim. 2013. "The Relationship between Civic Attitudes and Voting Intention: An Analysis of Vocational Upper Secondary Schools in England and Singapore." Compare. http://dx.doi.org/10.1080/ 03057925.2013.780874.

Haste, Helen. 2004. "Constructing the Citizen." Political Psychology 25 (3): 413-439.

Hayduk, L. A. 1997. LISREL. Issues, Debates and Strategies. Baltimore, MD: John Hopkins University Press.

Hooghe, M. 2004. "Political Socialization and the Future of Politics." Acta Politica 39 (4): 331-341.

Hooghe, M., and D. Stolle. 2004. "Good Girls Go to the Polling Booth, Bad Boys Go Everywhere. Gender Differences in Anticipated Political Participation among US 14 Year Olds." Women and Politics 26 (3-4): 1-23.

Hooghe, M., and B. Wilkenfeld. 2008. "The Stability of Political Attitudes and Behaviors across Adolescence and Early Adulthood: A Comparison of Survey Data on Adolescents and Young Adults in Eight Countries." Journal of Youth and Adolescence 37 (2): 155-167.

Hoyle, R. H., ed. 1995. "The Structural Equation Modeling Approach. Basic Concepts and Fundamental Issues." In Structural Equation Modeling: Concepts, Issues, and Applications, edited by R. H. Hoyle, 1-15. Thousand Oaks, CA: Sage.

Hyland, N. E. 2006. "Detracking in the Social Studies: A Path to a More Democratic Education?" Theory into Practice 45 (1): 64-71.

Ichilov, O. 2002. "Differentiated Civics Curriculum and Patterns of Citizenship Education: Vocational and Academic Programs in Israel." In Citizenship Education and the Curriculum, edited by D. Scott and H. Lawson, 81-109. Westport, CT: Greenwood.

Iversen, T., and J. D. Stephens. 2008. "Partisan Politics, the Welfare State and Three Worlds of Human Capital Formation." Comparative Political Studies 41 (4-5): 600-637. 
Janmaat, J. G., and N. Mons. 2011. "Promoting Ethnic Tolerance and Patriotism: The Role of Education System Characteristics." Comparative Education Review 55 (1): 56-81.

Kahne, J., N. Lee, and J. Feezell. 2013. "The Civic and Political Significance of Online Participatory Cultures among Youth Transitioning to Adulthood." Journal of Information Technology \& Politics 10 (1): 1-20.

Kam, C. D., and C. L. Palmer. 2011. "Rejoinder: Reinvestigating the Causal Relationship between Higher Education and Political Participation." Journal of Politics 73 (3): 659-663.

Lauglo, J., and T. Øia. 2006. Education and Civic Engagement among Norwegian Youths. Oslo: Norwegian Social Research.

Levinson, M. 2010. "The Civic Empowerment Gap: Defining the Problem and Locating Solutions." In Handbook of Research on Civic Engagement in Youth, edited by R. Sherrod, J. Torney-Purta, and C. A. Flanagan, 331-362. Hoboken, NJ: John Wiley \& Sons.

Mostafa, T., C. Edmonds, J. Preston, A. Green, A. Jenkins, and C. Chadderton. 2011. The Meso-Social Benefits of Vocational Education and Training for Social Groups and Communities. London: Institute of Education.

Niemi, R., and J. Junn. 1998. Civic Education: What Makes Students Learn. New Haven, CT: Yale University Press.

Persson, M. 2012. "Does Type of Education Affect Political Participation? Results from a Panel Survey of Swedish Adolescents." Scandinavian Political Studies 35 (3): 198-221.

Persson, M., and H. Oscarsson. 2010. "Did the Egalitarian Reforms of the Swedish Educational System Equalise Levels of Democratic Citizenship?" Scandinavian Political Studies 33 (2): 135-163.

Power, F. C., and A. M. R. Power. 1992. "A Raft of Hope: Democratic Education and the Challenge of Pluralism." Journal of Moral Education 21 (3): 193-205.

Rice, T. W., and J. L. Feldman. 1997. "Civic Culture and Democracy from Europe to America." The Journal of Politics 59 (4): 1143-1172.

Rubin, B. C. 2007. "Laboratories of Democracy': A Situated Perspective on Learning Social Studies in Detracked Classrooms." Theory and Research in Social Education 35 (1): 62-95.

Scholz, U., B. G. Dona, S. Sud, and R. Schwarzer. 2002. "Is General Self-Efficacy a Universal Construct?: Psychometric Findings from 25 Countries." European Journal of Psychological Assessment 18 (3): 242-251.

Schulz, W., J. Ainly, J. Fraillon, D. Kerr, and B. Losito. 2010. ICCS 2009 International Report: Civic Knowledge, Attitudes and Engagement among Lower Secondary School Students in 38 Countries. Amsterdam: IEA.

Sears, D., and S. Levy. 2003. "Childhood and Adult Political Development." In Oxford Handbook of Political Psychology, edited by D. Sears, L. Huddy, and R. Jervis, 60-109. Oxford: Oxford University Press.

Stevens, Frank. 2002. "Growing up in a Symbolic Society: The Difference between 'Spirou' and 'Tintin': Gender and Educational Tracking in the Social and Cultural Practices of Young People in Flanders." Paper presented at the Xth SWS-Dagen, Amsterdam, May 30-31, and the XV World Congress of Sociology, Brisbane, Australia, July 7-13.

Ten Dam, G. T. M., and M. Volman. 2003. "A Life Jacket or an Art of Living: Social Competence and the Reproduction of Inequality in Education." Curriculum Inquiry 33 (2): 117-137. 
van de Werfhorst, Herman G. 2007. Vocational Education and Active Citizenship: Behaviour in Cross-National Perspective. AIAS Working Papers Number 1007-62. Amsterdam: University of Amsterdam. Accessed September 22, 2011. http://www.uva-aias.net/uploaded_files/publications/WP62.pdf

van de Werfhorst, Herman G. 2009. Education, Inequality, and Active Citizenship: Tensions in a Differentiated Schooling System. Working Paper, 09-73. Amsterdam: Amsterdam Institute for Advanced Labour Studies, University of Amsterdam.

Verba, S., K. Schlozman, and H. Brady. 1995. Voice and Equality: Civic Voluntarism in American Politics. London: Harvard University Press.

Veugelers, Wiel. 2007. "Creating Critical-Democratic Citizenship Education: Empowering Humanity and Democracy in Dutch Education." Compare 37 (1): 105-119.

Veugelers, W., and P. Vedder. 2003. "Values in Teaching." Teachers and Teaching: Theory and Practice 9 (4): 377-389. 